\title{
Influence of Steric Hindrance on the Antioxidant Activity of Some Schiff Base Ligands and Their Copper (II) Complexes
}

\author{
MUHAMMAD SALEH SALGA ${ }^{1}$, IBRAHIM SADA ${ }^{1}$ and ABDULLAHI MUSTAPHA ${ }^{2}$ \\ 'Department of Pure and Industrial Chemistry, Umaru Musa Yar'adua University, Katsina, Nigeria. \\ ${ }^{2}$ Department of Chemistry, Federal University Dutse, PMB 7156 Jigawa State, Nigeria \\ ${ }^{*}$ Corresponding author E-mail: salgamohd@yahoo.com \\ http://dx.doi.org/10.13005/ojc/300410
}

(Received: August 01, 2014; Accepted: September 01, 2014)

\begin{abstract}
Herein we report the synthesis, characterization and antioxidant activity of the Schiff base ligands (E)-4-bromo-2-((2-piperazine-1-yl)ethylimino)methylphenol and 2,2'-(1E,1E')-cyclohexane1,2-diylbis(azan-1-yl-1-ylidene))bismethan-1-yl-1-ylidene)bis (4-bromophenol) and their complexes of copper (II) ion. Antioxidant activities of the copper complexes were studied by ferric reducing antioxidant power (FRAP) assay according to the procedure reported by Benzie and Strain ${ }^{1}$ which considered the reduction of ferric tripyridyl triazine complex to a ferrous complex at low $\mathrm{pH}$ by monitoring the change in absorption at $593 \mathrm{~nm}$. The overall results showed an increased in antioxidant activity with the increase in steric crowd. Similarly, the ligands show high activity than the complexes.
\end{abstract}

Key words: Synthesis, characterization, antioxidant activity.

\section{INTRODUCTION}

Interest in the symmetric and asymmetric synthesis of Schiff bases has increased significantly in recent years ${ }^{2}$. Diamines are known to coordinate to metal ions as bidentate ligands and forms both symmetric and asymmetric Schiff bases ${ }^{3}$. Being cancer one of the major leading diseases causing death in industrialized countries ${ }^{4}$, as such, development of anticancer therapies is one of the fundamental goals in medicinal chemistry. It is well known that free radicals can damage protein, lipids and DNA of bio-tissues leading to the increased rates of cancer ${ }^{1}$. Fortunately, antioxidant can prevent this damage due to their free radical scavenging activity $^{9}$. Hence it is of paramount importance to develop compounds with strong antioxidant activity and verify the factors affecting this biological activity. In this paper, we study the variation in antioxidant activity with increased steric crowd by measuring the activity of the Schiff base (E)-4-bromo-2-((2piperazine-1-yl)ethylimino)methylphenol [ $\left.\mathrm{L}_{1}\right]$ (less crowded) and 2,2'-(1E,1E')-cyclohexane-1,2diylbis(azan-1-yl-1-ylidene)) bismethan-1-yl-1ylidene)bis(4-bromophenol) $\left[\mathbf{L}_{2}\right]$ (more crowded) against their $\mathrm{Cu}(\mathrm{II})$ complexes. The results were compared with that of Gallic acid and Vitamin C which are employed as reference standards to 
ascertain the extent of antioxidant activity of the compounds under study.

\section{MATERIALS AND METHODS}

\section{Materials}

1-(2-Aminoethyl) piperazine, 5bromosalicylaldehyde, cyclohexane-1, 2-diamine and $\mathrm{CuCl}_{2}$ salts were purchased from SigmaAldrich. The spectroscopic grade DMSO- $d_{6}$ was obtained from Aldrich and all other solvents used were of analytical grade and used without further purifications.

\section{Synthesis of the Schiff base $\mathrm{L}_{1}$}

The Schiff bases and their copper complexes were prepared according to the synthetic pathway shown in scheme1 and 2 following the procedure below:

A measured amount of 1-(2aminoethyl)piperazine $(0.13 \mathrm{~g}, 1 \mathrm{mmol})$ was dissolved in an absolute ethanol and added drop wise to the stirred ethanolic solution of $(0.2 \mathrm{~g}, 1 \mathrm{mmol})$ Bromosalicylaldehyde at room temperature. The mixture is then refluxed for $1 \mathrm{hr}$ to give orange solution. After evaporating the solution using rotary evaporator, red oil was formed which on addition of solid sodium perchlorate $(0.1 \mathrm{~g})$ produces yellow needle-like crystalline solids. Recrystallization was performed in methanol-chloroform mixture.

\section{Synthesis complex [ $\left.\mathrm{CuL}_{1}\right]$}

A stoichiometric amount of $\mathrm{CuCl}_{2}(0.17 \mathrm{~g}$, $1 \mathrm{mmol})$ was dissolved in methanol and added to the stirred methanolic solution $(0.3 \mathrm{~g}, 1 \mathrm{mmol})$ of the ligand at room temperature. A green precipitate was formed, which after stirring for $5 \mathrm{~min}$ and settled is filtered. The filtrate is concentrated using rotary evaporator which on standing for 10 days gives black crystals. The crystals were isolated by filtration, washed with methanol and recrystallized to give pure and quality crystals.

\section{Synthesis of the Schiff base $\mathrm{L}_{2}$}

Calculated amount of cyclohexane-1, 2diamine $(0.14 \mathrm{~g}, 1 \mathrm{mmol})$ was dissolve in an absolute ethanol and added drop wise to the stirred ethanolic solution $(0.2 \mathrm{~g}, 1 \mathrm{mmol})$ of Bromosalicylaldehyde at room temperature and then refluxed for $1 \mathrm{hr}$, to give yellow crystals. The crystals were removed by filtration, recrystallized in methanol and dried in a vacuum for further analysis.

\section{Synthesis of complex $\left[\mathrm{CuL}_{2}\right]$}

A stoichiometric amount of $\mathrm{CuCl}_{2}(0.17 \mathrm{~g}$, $1 \mathrm{mmol})$ was dissolved in methanol and added to the stirred methanolic solution $(0.48 \mathrm{~g}, 1 \mathrm{mmol})$ of the ligand at room temperature. A green precipitate was formed after stirring for about 2 min which was allowed to settle and then filtered and dried in a vacuum.

Mass Spectra

The mass spectra of the ligand L1 was

Table 1

\begin{tabular}{ll}
\hline Compounds & $\mathrm{m} / \mathbf{z}$ \\
\hline $\mathrm{L} 1\left(\mathrm{C}_{13} \mathrm{H}_{18} \mathrm{BrN}_{3} \mathrm{O}\right)$ & $130,312,313,314,312$, \\
$\mathrm{L} 2\left(\mathrm{C}_{20} \mathrm{H}_{20} \mathrm{Br}_{2} \mathrm{~N}_{2} \mathrm{O}_{2}\right)$ & $467.19,479.9,481.9,477.9,480.9,478,482,483,480$ \\
\hline
\end{tabular}

Table 2

\begin{tabular}{lccccccccc}
\hline Compound & $\begin{array}{r}v(\mathrm{~N}-\mathrm{H}) \\
\text { aliphatic }\end{array}$ & $\begin{array}{c}v(\mathrm{C}-\mathrm{H}) \\
\text { Aromatic }\end{array}$ & $\begin{array}{c}v(\mathrm{C}=\mathrm{N}) \\
\mathrm{N})\end{array}$ & $\begin{array}{c}v(\mathrm{C}-\mathrm{C}) \\
\text { Arom })\end{array}$ & $\begin{array}{c}v(\mathrm{C}- \\
\text { aromatic }\end{array}$ & $\begin{array}{c}v(\mathrm{O}-\mathrm{M}- \\
\mathrm{O})\end{array}$ & $\begin{array}{c}v(\mathrm{M}- \\
\mathrm{N})\end{array}$ \\
\hline $\mathrm{L} 1\left(\mathrm{C}_{13} \mathrm{H}_{18} \mathrm{BrN}_{3} \mathrm{O}\right)$ & 3421 & 2736 & 1638 & 1458 & 1176 & 3421 & 688 & - & - \\
$\mathrm{CuL} 1\left(\mathrm{C}_{13} \mathrm{H}_{18} \mathrm{BrN}_{3} \mathrm{O}\right)$ & 3413 & 2947 & 1635 & 1478 & 1182 & - & 694 & 624 & 554 \\
$\mathrm{~L} 2\left(\mathrm{C}_{20} \mathrm{H}_{20} \mathrm{Br}_{2} \mathrm{~N}_{2} \mathrm{O}_{2}\right)$ & none & 2926 & 1630 & 1475 & 1184 & 3434 & 628 & - & - \\
$\mathrm{CuL} 2\left(\mathrm{C}_{20} \mathrm{H}_{20} \mathrm{Br}_{2} \mathrm{~N}_{2} \mathrm{O}_{2}\right)$ & none & 2935 & 1630 & 1455 & 1175 & - & 647 & 570 & 513 \\
\hline
\end{tabular}


recorded at room temperature and showed a molecular ion peak at m/z 130 which is assignable to the decomposition of $\mathrm{N}$-(Aminoethyl)piperazine

Table 3

\begin{tabular}{lccccc}
\hline Compound & \multicolumn{5}{c}{ Chemical shifts in ppm } \\
\cline { 2 - 6 } & $\mathrm{O}-\mathrm{H}$ & $\mathrm{N}-\mathrm{H}$ & $\mathrm{CH}_{2}$ & $\mathrm{Ar}-\mathrm{Br}$ & $\mathrm{C}=\mathrm{N}$ \\
\hline $\mathrm{L} 1$ & 4.32 & 2.17 & 2.51 & 7.37 & 8.29 \\
$\mathrm{~L} 2$ & 3.5 & none & 2.52 & 7.25 & 8.98 \\
\hline
\end{tabular}

Table 4

\begin{tabular}{|c|c|c|c|c|c|}
\hline \multicolumn{2}{|c|}{ Compound } & \multirow{2}{*}{$\begin{array}{c}\text { Wave } \\
\text { length }\end{array}$} & Absorption & \multicolumn{2}{|c|}{ Description } \\
\hline \multirow[t]{4}{*}{ L1 } & & & 3.073 & & $\pi-\pi^{*}$ \\
\hline & & 303 & 3.135 & & $n-\pi^{*}$ \\
\hline & & 312 & 3.135 & & $\mathrm{n}-\pi^{*}$ \\
\hline & & 344 & 3.135 & & $\mathrm{n}-\pi^{*}$ \\
\hline \multirow[t]{2}{*}{ L2 } & & 267 & 2.916 & & $\pi-\pi^{*}$ \\
\hline & & 321 & 3.263 & & $n-\pi^{*}$ \\
\hline \multirow{3}{*}{\multicolumn{2}{|c|}{ CuL1 }} & 274 & 2.552 & & $\pi-\pi^{*}$ \\
\hline & & 377 & 1.554 & & $-\mathrm{MCT}$ \\
\hline & & 636 & 0.144 & & $d-d$ \\
\hline \multirow[t]{3}{*}{ CuL2 } & & 272 & 2.592 & & $\pi-\pi$ \\
\hline & & 372 & 1.418 & & -MCT \\
\hline & & 588 & 0.354 & & $d-d$ \\
\hline \multicolumn{6}{|c|}{ Table 5: Antioxidant activity } \\
\hline 200 & 0.263 & 0.261 & 0.256 & 0.26 & 0.144 \\
\hline 400 & 0.379 & 0.41 & 0.383 & 0.391 & 0.275 \\
\hline 600 & 0.52 & 0.545 & 0.585 & 0.55 & 0.434 \\
\hline 800 & 0.707 & 0.703 & 0.704 & 0.705 & 0.589 \\
\hline 1000 & 0.841 & 0.809 & 0.925 & 0.858 & 0.742 \\
\hline
\end{tabular}

and another peak at $\mathrm{m} / \mathrm{z} 311.06(100 \%)$ which is attributed to the decomposition of the whole compound. Other peaks were observed at $313(97 \%), 314(14.8 \%), 312(14.3 \%)$. While the Ligand L2 shows molecular ion peaks at of 467(100\%), 479(97\%), 481(51.33\%), 477(51.2\%), $480(21.9 \%)$ and $478(11.5 \%)$. As shown in the table below

\section{Infra red spectra}

The IR spectra of the ligand L1 showed a broad band in the region $3400 \mathrm{~cm}^{-1}$ which is assignable to $\mathrm{N}-\mathrm{H}$ amine group. Appearance of this peak in the spectra of both the ligand and its $\mathrm{Cu}$ (II) complex indicates that the secondary amine at the extreme end of the structure is free from complexation. However, the spectrum of the ligand shows sharp absorption at $1640 . \mathrm{cm}^{-1}$ which is due to azomethine $-\mathrm{C}=\mathrm{N}$-, this absorption seems to shift to a lower frequency in the spectra of the complex which indicates the involvement $-\mathrm{C}=\mathrm{N}$ - nitrogen in the coordination to metal ion ${ }^{5,6}$. Assignment of the proposed coordination site is further supported by the appearance of medium bands at $554 \mathrm{~cm}-1$ which could be attributed to $1 / 2(\mathrm{M}-\mathrm{N})$ and $624 \mathrm{~cm}-1$ for $v(\mathrm{M}$ O) $)^{7,3}$.

The spectra of the ligand L2 shows sharp absorption $1630 . \mathrm{cm}^{-1}$ which is assignable to $\mathrm{C}=\mathrm{N}$ - of the azomethine, this absorption drops to a lower frequency of 1630 . $-1591 . \mathrm{cm}-1$ in the complex indicating the coordination of $-\mathrm{C}=\mathrm{N}$ - to the central metal ion. Also, the proposed coordination site was supported by the appearance of band regions at $513 \mathrm{~cm}-1$ for $v(M-N)$ and $570 \mathrm{~cm}-1$ which is assignable to $v(\mathrm{M}-\mathrm{O})$ respectively as shown in the table below

Table 6

\begin{tabular}{lcccccc}
\hline Samples & rep1 & rep2 & rep3 & Mean & avg-blnk & frap value \\
\hline L2 & 0.245 & 0.239 & 0.235 & 0.240 & 0.124 & 176.7 \\
L1 & 0.215 & 0.23 & 0.219 & 0.221 & 0.105 & 150.5 \\
CuL2 & 0.182 & 0.16 & 0.175 & 0.172 & 0.056 & 80.5 \\
CuL1 & 0.155 & 0.137 & 0.147 & 0.146 & 0.030 & 43.3 \\
GA 10x & 2.227 & 2.134 & 2.135 & 2.165 & 2.049 & 2927.6 \\
AA 10x & 1.161 & 1.1156 & 1.234 & 1.170 & 1.054 & 1506.0 \\
\hline
\end{tabular}




\section{${ }^{1} \mathrm{H}-\mathrm{NMR}$ spectra}

The HNMR spectra of the compound L1 was recorded in $\mathrm{CDCl}_{3}$ and the following signals were observed. $\mathrm{N}-\mathrm{H}$ amine was observed at 2.17ppm, methylene $\left(\mathrm{CH}_{2}\right)$ with 1- $\alpha-\mathrm{N}(\mathrm{C}) \mathrm{C}$ and 1$\beta-\mathrm{N}-\mathrm{C}$ at 2.51ppm, the chemical shift at 4.32ppm can be assign to aromatic alcohol while at $7.37 \mathrm{ppm}$ the shift can be attributed to aromatic bromide. Azomethine was observed at $8.29 \mathrm{ppm}$.

The spectrum of the $\mathrm{L} 2$ shows aromatic alcohol at 3.5ppm, methylene $\mathrm{CH}_{2}$ at 2.52ppm, aromatic bromide at $7.25 \mathrm{ppm}$ and azomethine at 8.98 as shown in table 3.

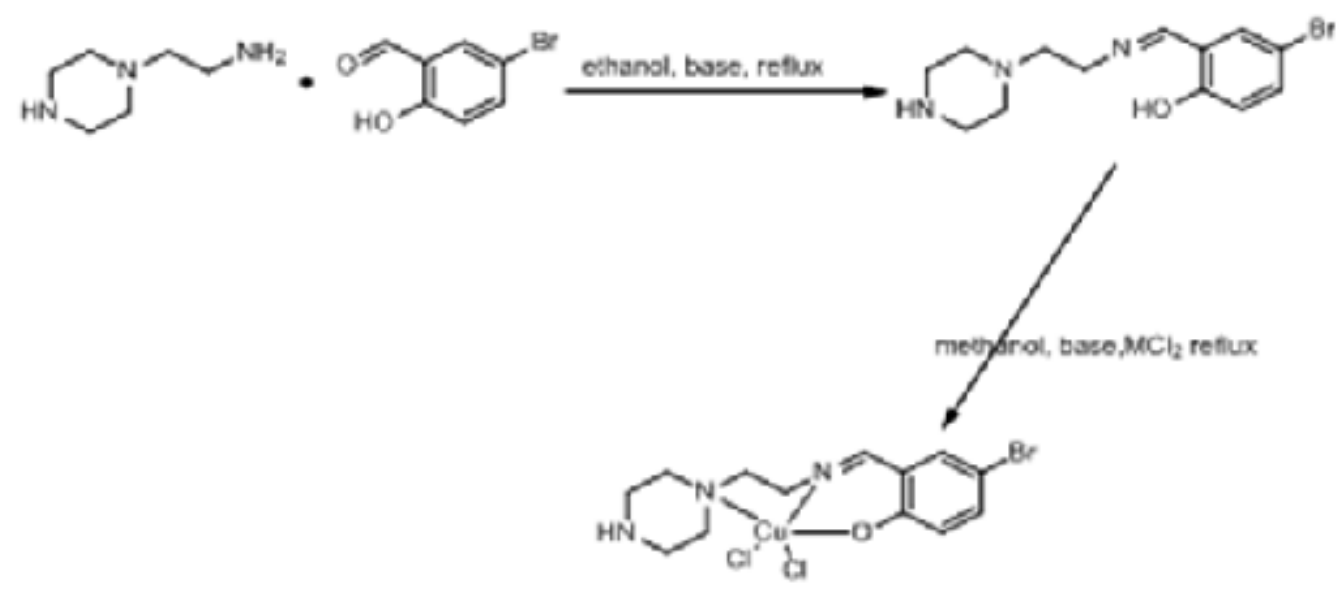

Scheme 1

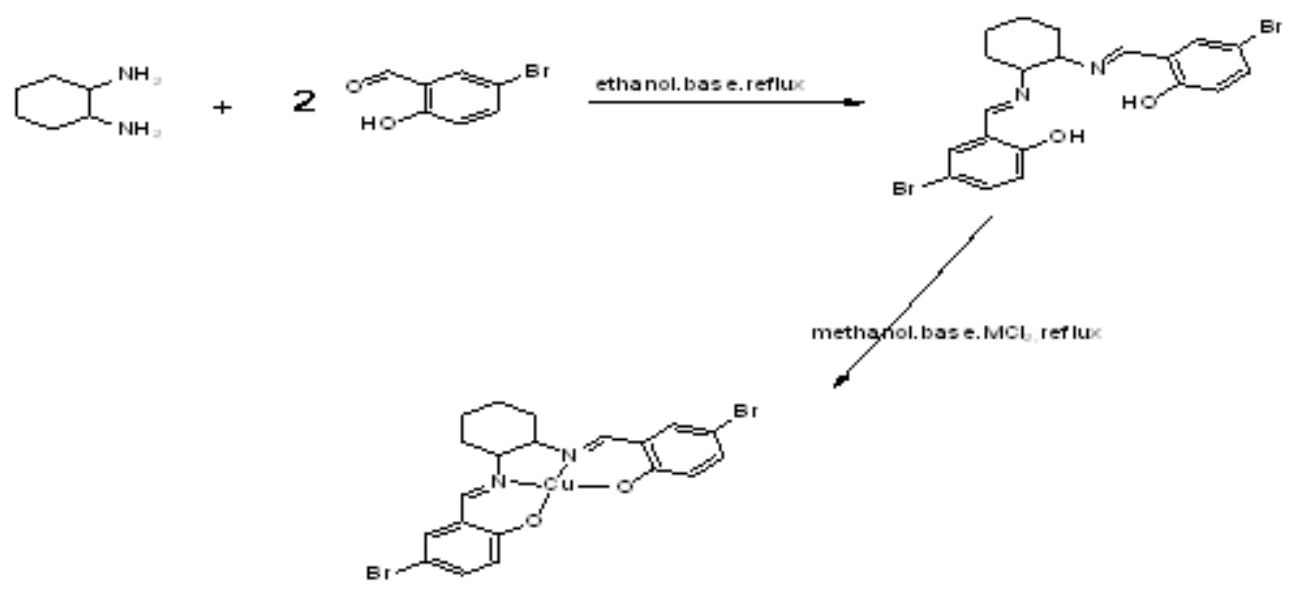

Scheme 2

Physical and analytical data

\begin{tabular}{|c|c|c|c|c|c|c|c|}
\hline \multirow[t]{2}{*}{ Compound } & \multirow[t]{2}{*}{ Formula } & \multirow[t]{2}{*}{ Colour } & \multirow[t]{2}{*}{ M.P/D.T } & \multirow[t]{2}{*}{ \%Yeid } & \multicolumn{3}{|c|}{ Calc.(found) } \\
\hline & & & & & C & H & $\mathbf{N}$ \\
\hline L1 & $\mathrm{C}_{13} \mathrm{H}_{18} \mathrm{BrN}_{3} \mathrm{O}$ & red & 40 & 72 & $50(48)$ & $5.8(5.6)$ & $13.5(12.9)$ \\
\hline L2 & $\mathrm{C}_{20} \mathrm{H}_{20} \mathrm{Br}_{2} \mathrm{~N}_{2} \mathrm{O}_{2}$ & yellow & 130 & 87 & $50(48.7)$ & $4.2(3.9)$ & $5.8(4.9)$ \\
\hline CuL1 & $\mathrm{Cu}\left(\mathrm{C}_{13} \mathrm{H}_{18} \mathrm{BrN}_{3} \mathrm{O}\right)$ & deep green & 328 & 65 & $35(34)$ & $3.8(3.6)$ & $9.4(9.2)$ \\
\hline CuL2 & $\mathrm{Cu}\left(\mathrm{C}_{20} \mathrm{H}_{20} \mathrm{Br}_{2} \mathrm{~N}_{2} \mathrm{O}_{2}\right)$ & green & 346 & 80 & $39(36)$ & $2.9(2.8)$ & $4.6(4.5)$ \\
\hline
\end{tabular}


Frap assay Standard Curve

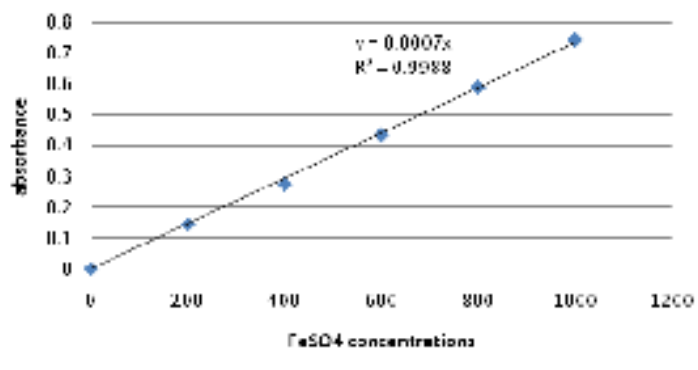

Fig. 1

\section{UV-Visible}

The UV-Visible spectra of the complexes were carried out in DMSO and their tentative assignments are as follows:

The spectra of L1 shows absorption of 3.073 at $279 \mathrm{~nm}$ which is assignable to $\pi-\pi^{*}$ electronic transition this is followed with a bathochromic shift at wavelength $303 \mathrm{~nm}$ and remain constant at wavelengths $312 \mathrm{~nm}$, and $344 \mathrm{~nm}$, this is attributed to $\mathrm{n}-\pi^{*}$ electronic transition due to nitrogen groups found in the various part of the ligand. However, the spectra of its complex (CuL1) shows absorption of 2.552 at $274 \mathrm{~nm}$ which is assignable to $\pi-\pi^{*}$ this absorption then move to a high wavelength of $377 \mathrm{~nm}$ which is very close to the wavelength of $344 \mathrm{~nm}$ found in the ligand and can be attributable to ligand-metal charge transfer, another absorption at $636 \mathrm{~nm}$ was observed and can be assign to $d$-d electronic transition in $\mathrm{Cu}$ (II). The spectra of $L 2$ shows absorption at $267 \mathrm{~nm}$ which correspond to $\pi-\pi^{*}$ electronic transition, a bathochromic shift occur at $321 \mathrm{~nm}$ which is assignable to $n-\pi^{*}$ electronic transition, its CuL2 complex shows absorption at $272 \mathrm{~nm}$ which can be attributed to $\pi-\pi^{*}$ electronic transition, another absorption at $372 \mathrm{~nm}$ in relation to the absorption at $321 \mathrm{~nm}$ in the spectra of the ligand can be assignable to ligand-metal charge transfer, while absorption at $588 \mathrm{~nm}$ can be attributed to $d-d$ electronic transition as shown in the table 4 below.

\section{Biological Activity}

The antioxidant activity results presented in figure 13 showed that the synthesized ligands and their metal (II) complexes posses antioxidant activity. The compounds were screened for their antioxidant activity and the scavenging ability of

\section{Frap Assay vs compounds}

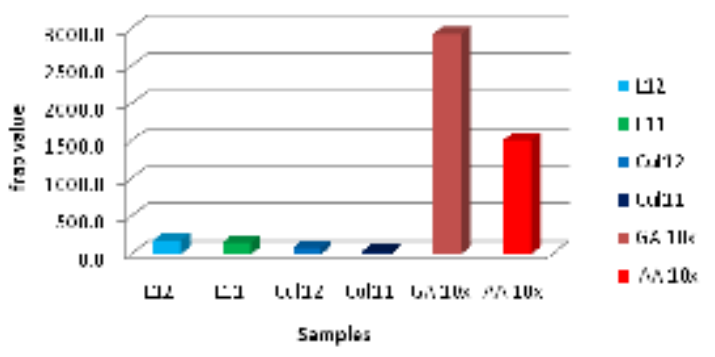

Fig. 2

the ligands as well as their complexes against hydroxyl radicals were tested as a function of concentration from $0-0.8 \mu \mathrm{M}$ as shown in figure 13 . It can be seen that the inhibitory effects of complexes on the hydroxyl radicals are related to concentration. The scavenging activities was found to be more on the ligands than on their $\mathrm{Cu}(\mathrm{II})$ complexes and is increase with increasing steric crowding according to the following order L2 $>$ L1 $>$ CuL2 $>$ CuL1 detail was shown on the tables $5 \& 6$ and figures $1 \& 2$ below.

\section{CONCLUSION}

The synthesized compounds showed antioxidant properties. By comparison, the ligands showed high antioxidant activity than their $\mathrm{Cu}$ (II) complexes. However, none of the compounds were found to have high activity than vitamin $C$ and/or Gallic acid. L2 reveals the highest radical scavenging activity among the series whereas the compound CuL1 reveals the lowest. The different relative scavenging activity of the individual compounds against different radicals may be attributed to steric crowd, number of free hydroxyl groups and other factors such as stereoselectivity of the radicals or the solubility of these compounds in different testing systems may also affect the capacity of individual compounds to react and quench different radicals ${ }^{8}$.

\section{ACKNOWLEDGMENTS}

The authors acknowledged the financial support from TETFUND, the Department of Pure and Industrial Chemistry where the research work is conducted and Umaru Musa Yaradua University for providing the facilities for this study. 


\section{REFERENCES}

1. Benzie, F.F.; and J.J. Strain, J.J. Method Enzymol. 1999, 299:15-23

2. Dreher, D.; and Junod, A. F. Eur. J. Cancer. 1996, 32: 30.

3. Katsuki, T. Chem. Soc. Rev., 2004, 33, 437444

4. Nakamoto, K. Infra red and Raman spectra of inorganic and coordination compounds, New York: Wiley $3^{\text {rd }}$ edition.

5 Barceo-Oliver, M.; Garcia-Raso, A.; Terron, A.; Molins, E.; Prieto, M.J.; Moreno, V. Martinez, J.; Llado, V.; lopez, I.; Gutierrrez, A.; Escriba,
P.V. J. Inorg. Biochem. 2007, 101:649

6. Iskander, M.F.; Ei-syed, L.; Ismail, K.Z. Trans. Met. Chem. 1979, 4: 225

7. Thankamony, M.; and Mohanan, K. Indian J. Chem. 2007, A46: 249

8. Thomas, M.; Nair, M.K.M.; Radhakrisan, R.K. Synth.Reac. Inorg. Met.-Org. Chem. 1995, 25 : 471

9. Wang S.Y.; and Jiao, H. J. Agirc. Food. Chem. 2000, 48: 5677-5684

10. Chen, W.J.; Guo, P.; Song, J.; Cao, W.; Bian, J. Bioorg. Med. Chem Lett. 2006, 16:3582 